\title{
PENGARUH SOSIALISASI PERPAJAKAN DAN SANKSI PERPAJAKAN TERHADAP KEPATUHAN WAJIB PAJAK UMKM E- COMMERCE
}

\author{
Afeni Maxuel \\ Anita Primastiwi \\ Program Studi S1 Akuntansi, Fakultas Ekonomi, Universitas Sarjanawiyata Tamansiswa \\ Email korespondensi: maxuelafeny@gmail.com
}

\begin{abstract}
ABSTRAK
Penelitian ini bertujuan untuk menguji apakah sosialisasi perpajakan, kesadaran wajib pajak dan sanksi perpajakan berpengaruh terhadap kepatuhan wajib pajak UMKM e-commerce. Metode penelitian ini menggunakan metode deskriptif kuantitatif dan data primer dengan menggunakan kuesioner. Penelitian mengambil sampel pengusaha $e$-commerce yang ada di Indonesia. Teknik pengambilan sampel menggunakan purposive sampling. Pengumpulan data dilakukan dengan cara mengirimkan kuesioner melalui chat personal atau melalui e-mail dalam bentuk google form kepada pengusaha e-commerce. Jumlah kuesioner yang diolah adalah 100 kuesioner. Data dianalisis menggunakan analisis regresi linear berganda. Hasil penelitian ini menunjukkan bahwa sosialisasi perpajakan berpengaruh positif terhadap kepatuhan wajib pajak UMKM e-commerce sedangkan kesadaran wajib pajak dan sanksi perpajakan tidak berpengaruh signifikan terhadap kepatuhan wajib pajak UMKM e-commerce. Kata kunci: sosialisasi perpajakan, kesadaran wajib pajak, sanksi perpajakan, kepatuhan wajib pajak, umkm e-commerce.
\end{abstract}

\begin{abstract}
This study aims to examine whether taxation socialization, awareness of taxpayers and tax sanctions affect the tax compliance of MSME e-commerce taxpayers. This research method uses quantitative descriptive methods and primary data using a questionnaire. The study took a sample of e-commerce entrepreneurs in Indonesia. The sampling technique uses purposive sampling. Data collection is done by sending questionnaires via personal chat or via e-mail in the form of Google forms to e-commerce entrepreneurs. The number of questionnaires processed was 100 questionnaires. Data were analyzed using multiple linear regression analysis. The results of this study indicate that taxation socialization has a positive effect on tax compliance of MSME e-commerce taxpayers while awareness of taxpayers and tax sanctions does not have a significant effect on tax compliance of MSME e-commerce taxpayers Keywords: taxation socialization, taxpayer awareness, tax sanction, taxpayer compliance, ecommerce SME.
\end{abstract}




\section{PENDAHULUAN}

Dalam era globalisasi yang terjadi saat ini perkembangan teknologi informasi dan komunikasi semakin meningkat. Peningkatan tersebut ditandai dengan adanya internet. Sebagian besar pengguna internet secara aktif rata-rata menghabiskan waktu lebih dari 5 (lima) jam perhari untuk mengakses internet, hampir dari setengah waktu mereka digunakan untuk mengakses media sosial. Berdasarkan hasil riset Wearesosial Hootsuite yang dirilis Januari 2019 pengguna media sosial di Indonesia mencapai 150 juta atau sebesar 56\% dari total populasi. Jumlah tersebut naik 20\% dari survei sebelumnya. Sementara pengguna media sosial mobile (gadget) mencapai 130 juta atau sekitar 48\% dari populasi. Besarnya populasi, pesatnya pertumbuhan pengguna internet dan telepon merupakan potensi bagi ekonomi digital nasional. Alhasil, muncul ecommerce, transportasi online, toko online dan bisnis lainnya berbasis internet di tanah air. Ini akan menjadi kekuatan ekonomi digital di kawasan Asia Tenggara (katadata.co.id).

Sebagian besar pengguna internet memanfaatkannya untuk e-commerce. $e$ commerce didefinisikan sebagai transaksi pembelian dan penjualan barang dan jasa secara fisik menggunakan peralatan komunikasi elektronik, seperti telepon, komputer pribadi, online kios, Automatic Teller Machine (ATM), smart card atau smart phone, melalui saluran telekomunikasi seperti jaringan telepon publik tradisional, jaringan komputer, jaringan komputer bergerak, dan sejenisnya.

Perdagangan elektronik memang memberikan keuntungan baik bagi pedagang maupun para konsumen/pembeli sehingga penggunaan internet dalam melakukan transaksi masih diminati dan diprediksi akan menggantikan transaksi yang masih menggunakan pola konvensional yaitu transaksi di mana pembeli dan penjual saling berhadapan atau bertemu muka untuk pembayaran dan penyerahan barang. Jadi dapat kita ketahui bahwa wajib pajak tidak hanya mereka yang bekerja menjadi pegawai diperusahaan saja, tetapi yang berpenghasilan dari media sosial pun wajib mendaftarkan dirinya menjadi wajib pajak.

Menurut Undang-Undang No 16 tahun 2009, pajak adalah kontribusi wajib kepada Negara yang terutang oleh orang pribadi atau badan yang bersifat memaksa berdasarkan undang-undang, dengan tidak mendapatkan imbalan secara langsung dan digunakan untuk keperluan Negara bagi sebesar-besarnya kemakmuran rakyat. Oleh karena itu Indonesia termasuk salah satu Negara yang mengandalkan penerimaan pajak sebagai penopang APBN-nya, karena pajak merupakan penerimaan terbesar Negara. Terlihat dari penerimaan APBN tahun 2019 sebesar Rp 1.786,4 triliun, pajak menyumbang sebesar Rp 1.634,3 triliun ini berarti pajak menyumbang $85 \%$ dari seluruh penerimaan Negara yang diungkapkan oleh Kementerian Keuangan Republik Indonesia pada tahun 2019.

Meskipun pendapatan disektor pajak lebih besar dibandingkan dari pendapatan di sektor lain, tetapi dalam penerimaan pajak UMKM E-commerce belum mencapai $100 \%$. Ketidak tercapaian ini dikarenakan kurangnya sosialisasi perpajakan, kesadaran wajib pajak dan lemahnya sanksi perpajakan. Kepatuhan pajak pelaku Usaha Mikro, Kecil, Dan Menengah (UMKM) masih minim. Dari 60 juta unit UMKM di Indonesia, baru sekitar 2,5 persen atau sebanyak 1,5 juta wajib pajak yang melaporkan pajaknya (Republika.co.id).

Dari data tersebut Kementerian Keuangan melalui Direktorat Jendral Pajak akhirnya secara resmi mengeluarkan peraturan mengenai pengenaan pajak bagi para pelaku e-commerce. Ketentuan tersebut tertuang dalam Peraturan Menteri Keuangan 210/PMK.010/2018 tentang perlakuan perpajakan atas transaksi perdagangan melalui sistem elektronik ( $e$ commerce). Dengan hadirnya regulasi ini 
bisa dipastikan bahwa Peraturan Menteri Keuangan (PMK) secara efektif akan berlaku per 1 april 2019. Aturan ini meliputi kewajiban penyedia platform marketplace seperti Blibli, Bukalapak, Elevenia, Lazada, Shopee, dan Tokopedia. Sekaligus pelaku over-the-top di bidang transportasi juga masuk sebagai platform marketplace.

Dalam regulasi tersebut ada beberapa hal yang dikenakan yakni; pertama, para pedagang dan penyedia jasa yang berjualan melalui platform marketplace diwajibkan melaksanakan kewajiban terkait PPh sesuai dengan ketentuan yang berlaku, seperti membayar pajak final dengan tarif 0,5\% dari omzet dalam hal omzet tidak melebihi Rp 4,8 miliar dalam setahun serta dikukuhkan sebagai pengusaha kena pajak dalam hal omzet melebihi Rp 4,8 miliar dalam setahun dan melaksanakan kewajiban terkait PPN sesuai ketentuan yang berlaku. Kedua, para penyedia platform marketplace diwajibkan untuk memungut, menyetor, serta melaporkan rekapitulasi transaksi yang dilakukan pedagang pengguna platform.

Dari penjelasan di atas dapat kita ketahui bahwa para pelaku UMKM ECommerce belum mengetahui dan mematuhi adanya pengenaan pembayaran pajak final dengan tarif $0,5 \%$. Hal ini lah yang nantinya akan menimbulkan ketidakpatuhan pada peraturan perundangundangan perpajakan dengan cara penghindaran pajak. Dari ketidakpatuhan inilah yang nantinya akan diperbaiki dengan beberapa cara yaitu, meningkatkan sosialisasi perpajakan dan meningkatkan kesadaran wajib pajak akan pentingnya pembayaran pajak. Sosialisasi perpajakan merupakan suatu upaya yang dilakukan untuk memberikan informasi mengenai perpajakan yang bertujuan agar seseorang ataupun kelompok paham tenang pajak sehingga kepatuhan wajib pajak akan meningkat (Sudrajat, 2015). Jika wajib pajak diberikan pemahaman yang baik dan benar melalui sosialisasi, maka wajib pajak akan memiliki pengetahuan tentang pentingnya membayar pajak. Wajib pajak seharusnya wajib mengikuti sosialisasi perpajakan karena semakin sering wajib pajak mendapatkan sosialisasi maka semakin ia mengerti akan perpajakan dan semakin tinggi kepatuhannya sebagai wajib pajak umkm e-commerce. Hal ini didukung oleh penelitian yang dilakukan oleh Jannah (2016), dan Anwar (2015) yang menyatakan bahwa sosialisasi perpajakan berpengaruh positif terhadap kepatuhan wajib pajak. Berbeda dengan penelitian Winerungan (2013) yang menyatakan bahwa sosialisasi perpajakan tidak berpengaruh.

Selain mendapatkan sosialisasi wajib pajak juga perlu mengetahui adanya sanksi yang menjadi alat kontrol bagi wajib pajak. Sanksi pajak merupakan jaminan bahwa ketentuan peraturan perundang-undangan perpajakan (norma perpajakan) akan dituruti/ditaati/dipatuhi, atau dengan kata lain sanksi perpajakan merupakan alat pencegah/preventi agar wajib pajak tidak melanggar norma perpajakan (Mardiasmo, 2016). Semakin berat sanksi yang dikenakan fiskus bagi wajib pajak yang melanggar peraturan perpajakan semakin ia sadar dan semakin tinggi kepatuhannya sebagai wajib pajak umkm e-commerce. Semua peraturan perpajakan telah diatur dalam undang-undang perpajakan termasuk masalah terkait sanksi pajak. Pelaksanaan sanksi pajak yang tegas sangat diperlukan untuk mengontrol kepatuhan wajib pajak, wajib pajak cenderung akan patuh apabila wajib pajak berpikir bahwa sanksi pajak sangat merugikan. Hal ini didukung oleh penelitian yang dilakukan oleh Vallianta (2014) dan Pertiwi (2017) yang menyatakan bahwa sanksi perpajakan memberikan pengaruh terhadap kepatuhan perpajakan. Tingkat kepatuhan perpajakan rendah terjadi kerena penerapan sanksi pajak yang kurang baik sehingga belum berjalan optimal. Berbeda dengan penelitian Winerungan (2013) sanksi perpajakan tidak memiliki pengaruh terhadap kepatuhan wajib pajak. Berdasarkan uraian di atas, maka penelitian 
JRMB, Volume 16, No. 1, Juni 2021

ini bertujuan untuk mengetahui pengaruh sosialisasi perpajakan dan sanksi perpajakan terhadap kepatuhan wajib pajak UMKM e-commerce.

\section{KAJIAN LITERATUR \\ Theory of Planned Behavior (TPB)}

Theory of planned behavior dikembangkan oleh Azjen pada tahun 1988. Teori ini disusun menggunakan asumsi dasar bahwa manusia berperilaku dengan cara yang sadar dan memperhatikan segala informasi yang tersedia. Theory of Planned Behavior merupakan teori yang dikembangkan oleh Ajzen yang merupakan penyempurna dari teori terdahulu yakni Theory Reasoned Action (TRA). Theory of Reasoned Action (TRA) mengemukakan bahwa niat melakukan atau tidak melakukan perilaku tertentu dipengaruhi oleh dua penentu dasar yakni perilaku yang berhubungan dengan sikap (attitude towards behavior) dan perilaku yang berhubungan norma subjektif (subjective norm).

\section{Sosialisasi Perpajakan}

Sosialisasi adalah suatu konsep umum yang dimaknakan sebagai proses belajar melalui interaksi dengan orang lain, tentang cara berfikir, merasakan dan bertindak dimana semuanya itu merupakan hal-hal yang sangat penting dalam menghasilkan partisipasi sosial yang efektif (Wurianti, 2015). Sosialisasi perpajakan adalah pemberian wawasan, dan pembinaan kepada wajib pajak agar mengetahui tentang segala hal mengenai perpajakan. Suragih, (2013) menyatakan bahwa sosialisasi perpajakan adalah sebagai bentuk upaya dari Direktorat Jendral Pajak untuk memberikan pengertian, informasi, dan pembinaan kepada masyarakat pada umumnya dan wajib pajak khususnya, mengenai segala sesuatu yang berhubungan dengan peraturan perundang-undang perpajakan.

\section{Sanksi Perpajakan}

Sanksi pajak merupakan jaminan bahwa ketentuan peraturan perundangundangan perpajakan (norma perpajakan) akan dituruti/ditaati/dipatuhi, dengan kata lain sanksi perpajakan merupakan alat pencegah agar wajib pajak tidak melanggar norma perpajakan yang telah ditetapkan Semakin tinggi atau beratnya sanksi, maka akan semakin merugikan wajib pajak (Mardiasmo, 2014).

Penerapan sanksi ditetapkan sebagai akibat tidak terpenuhinya kewajiban perpajakan oleh wajib pajak sebagaimana diamanatkan oleh undang-undang perpajakan. Pengenaan sanksi pajak kepada wajib pajak dapat menyebabkan terpenuhinya kewajiban perpajakan oleh wajib pajak sehingga dapat meningkatkan kepatuhan wajib pajak itu sendiri

\section{Kepatuhan Wajib Pajak}

Menurut Kamus Besar Bahasa Indonesia, kepatuhan berarti tunduk atau patuh pada ajaran atau aturan. Dalam hal pajak, aturan yang berlaku adalah aturan perpajakan. dengan adanya hubungan wajib pajak yang patuh, maka kepatuhan pajak artinya sebagai suatu keadaan wajib pajak memenuhi semua kewajiban perpajakan dan melaksanakan hal perpajakan (Rayahu, 2012). Kewajiban wajib pajak dalam melaksanakan kewajibannya membayar pajak merupakan faktor yang penting dalam hal upaya pemerintah untuk meningkatkan penerimaan pajak.

\section{Sosialisasi Perpajakan terhadap Kepatuhan Wajib Pajak}

Menurut Sudrajat et al. (2015), sosialisasi perpajakan berarti suatu upaya yang dilakukan untuk memberikan informasi mengenai perpajakan yang bertujuan agar seseorang ataupun kelompok paham tentang perpajakan sehingga kesadaran wajib pajak akan meningkat. Jika wajib pajak diberikan pemahaman yang baik dan benar melalui sosialisasi, maka wajib pajak akan memiliki pengetahuan tentang pentingnya membayar 
pajak. Kurangnya pengetahuan dan wawasan karena rendahnya sosialisasi perpajakan akan menyebabkan mereka tidak memahami bagaimana caranya melaksanakan kewajiban perpajakan dan pada akhirnya tidak melaksanakan kewajiban perpajakannya. Sosialisasi perpajakan membantu meningkatkan pengetahuan wajib pajak tentang pentingnya membayar pajak sehingga akan meningkatkan kepatuhan wajib pajak yang pada akhirnya meningkatkan penerimaan negara dari sektor pajak. Semakin tinggi sosialisasi perpajakan semakin tinggi pula kepatuhan wajib pajak (Ananda at al., 2015). Berdasarkan uraian hasil penelitian diatas maka dapat ditarik hipotesis sebagai berikut:

$\mathrm{H}_{1}$ : Sosialiasi Perpajakan Berpengaruh Positif terhadap Kepatuhan Wajib Pajak UMKM E-Commerce.

\section{Sanksi Perpajakan Terhadap Kepatuhan Wajib Pajak}

Sanksi pajak merupakan jaminan bahwa ketentuan peraturan perundangundangan perpajakan (norma perpajakan) akan dituruti/ditaati/dipatuhi, dengan kata lain sanksi perpajakan merupakan alat pencegah agar wajib pajak tidak melanggar norma perpajakan yang telah ditetapkan (Mardiasmo, 2011). Sanksi perpajakan diberikan bukan untuk merugikan wajib pajak ataupun menguntungkan petugas pajak atau Negara, sanksi pajak diberikan agar wajib pajak taat akan peraturan pajak. Berdasarkan uraian hasil penelitian diatas maka dapat ditarik hipotesis sebagai berikut:
$\mathrm{H}_{2}$ : Sanksi Perpajakan Berpengaruh Positif terhadap Kepatuhan Wajib Pajak UMKM E-Commerce.

\section{METODE PENELITIAN \\ Teknik Pengumpulan Data}

Teknik pengumpulan data menggunakan kuesioner. Kuesioner diberikan kepada pengusaha yang sedang menjalankan bisnis E-Commerce. Teknik pengambilan sampel menggunakan metode purposive sampling. Adapun pertimbangan yang digunakan sebagai syarat dalam menentukan sampel adalah pengusaha yang sedang menjalankan bisnis melalui $E$ Commerce dan subjek penelitian berkenan mengisi kuesioner.

Kuesioner disebarkan secara langsung kepada pengusaha UMKM ECommerce, Responden yang mengisi kuesioner peneliti sebanyak 109 responden. 100 kuesioner dapat digunakan sebagai alat analisis, sedangkan 9 kuesioner tidak dapat digunakan sebagai alat analisis karena kuesioner dalam keadaan rusak sehingga tidak sesuai dengan kriteria yang ditentukan.

\section{Pengukuran Variabel}

Penelitian ini menggunakan satu variabel independen, yaitu Kepatuhan Wajib Pajak UMKM E-Commerce, sedangkan dua variabel dependen pada penelitian ini adalah Sosialisasi Perpajakan dan Sanksi Perpajakan. Data yang terkumpul dianalisis menggunakan program SPSS 17.0. seluruh jawaban kuesioner diukur dengan skala Likert 5 point yaitu $1=$ tidak setuju sampai dengan $5=$ sangat setuju. Instrumen penelitian ditunjukan pada tabel dibawah ini: 
Tabel 1. Konstruk dan Indikator Penelitian

\begin{tabular}{cl}
\hline Variabel & \multicolumn{1}{c}{ Instrumen } \\
\hline Kepatuhan Wajib Pajak UMKM E-Commerce & Kepatuhan dalam mendaftarkan diri ke kantor \\
& pajak. \\
& Kepatuhan dalam menghitung pajak dengan \\
& benar. \\
& Kepatuhan dalam membayar pajak dengan \\
& benar. \\
& Kepatuhan dalam melaporkan pajak dengan \\
& benar. \\
\hline Variabel & \multicolumn{1}{c}{ Instrumen } \\
\hline Sosialisasi Perpajakan & Penyelenggaraan Sosialisasi. \\
& Media Sosialisasi. \\
Sanksi Perpajakan & Manfaat Sosialisasi. \\
& Sanksi keterlambatan dan/atau tidak membayar \\
& pajak. \\
\hline
\end{tabular}

Sumber: Data diolah

\section{HASIL DAN PEMBAHASAN}

Penelitian ini menggunakan 2 variabel independen atau variabel bebas dan 1 variabel dependen atau terikat. Variabel independen dalam penelitian ini yaitu sosialisasi perpajakan dan kesadaran wajib pajak. Sedangkan variabel dependen dalam penelitian ini yaitu kepatuhan wajib pajak UMKM e-commerce. Pengujian statistik deskriptif dalam penelitian ini menggunakan program SPSS versi 17.0.

Tabel 2. Statistik Deskriptif

\begin{tabular}{cccccc}
\hline & N & Minimum & maksimum & Mean & $\begin{array}{c}\text { Std. } \\
\text { Deviation }\end{array}$ \\
\hline Sosialisasi & 100 & 34 & 67 & 46,63 & 5,811 \\
$\begin{array}{c}\text { Perpajakan } \\
\text { Sanksi Perpajakan }\end{array}$ & 100 & 20 & 40 & 28,66 & 3,906 \\
$\begin{array}{l}\text { Kepatuhan Wajib } \\
\text { Pajak UMKM E- }\end{array}$ & 99 & 28 & 70 & 54,19 & 8,016 \\
$\quad$ Commerce & & & & & \\
\hline
\end{tabular}

Sumber: Data primer diolah (2019)

Tabel 3. Hasil Uji Validitas

\begin{tabular}{cllcc}
\hline No. & \multicolumn{1}{c}{ Variabel/ Keterangan } & Keterangan \\
\hline 1 & Kepatuhan Wajib Pajak UMKM & $E-$ & Valid \\
& $\begin{array}{l}\text { Commerce } \\
2\end{array}$ & Sosialisasi Perpajakan & & Valid \\
3 & Kesadaran Wajib Pajak & Valid \\
4 & Sanksi Perpajakan & Valid \\
\hline
\end{tabular}

Sumber: Data primer diolah (2019)

Tabel 4. Hasil Uji Reliabilitas

\begin{tabular}{clc}
\hline No. & \multicolumn{1}{c}{ Variabel } & $\begin{array}{c}\text { Cronbach's } \\
\text { alpha }\end{array}$ \\
\hline 1 & Kepatuhan Wajib Pajak UMKM E- & 0,882 \\
& Commerce & \\
2 & Sosialisasi Perpajakan & 0,746 \\
3 & Sanksi Perpajakan & 0,820 \\
\hline \multicolumn{2}{l}{ Sumber: Data primer diolah (2019) }
\end{tabular}




\section{HASIL UJI HIPOTESIS \\ Sosialisasi Perpajakan Terhadap \\ Kepatuhan Wajib Pajak UMKM E- Commerce}

Berdasarkan hasil pengujian

hipotesis, hipotesis pertama yaitu sosialisasi perpajakan berpengaruh terhadap kepatuhan wajib pajak UMKM $e$ commerce. Hal ini dibuktikan dengan nilai signifikan 0,000 $<0,05$ dan unstandardized coefficients $\mathrm{B}$ sebesar 0,473 sehingga $\mathrm{H}_{1}$ diterima, hal ini berarti bahwa sosialisasi perpajakan berpengaruh secara signifikan terhadap kepatuhan wajib pajak UMKM $e$ commerce. Hasil pengujian ini membuktikan bahwa kepatuhan wajib pajak UMKM e-commerce akan meningkat apabila wajib pajak mengikuti sosialisasi perpajakan seperti seminar dan penyuluhan pajak selain itu karena informasi tentang pajak sudah dapat diketahui melalui media cetak, media elektoronik yaitu spanduk, iklan dan website pajak sehingga wajib pajak mudah mendapatkan informasi tentang pajak. Dengan mengikuti sosialisasi perpajakan, dapat meningkatkan motivasi, pengetahuan dan wawasan wajib pajak untuk berperilaku patuh terhadap kewajiban perpajakannya.

\section{Sanksi Perpajakan Terhadap Kepatuhan Wajib Pajak UMKM E- Commerce}

Berdasarkan hasil pengujian hipotesis, hipotesis kedua yaitu sanksi perpajakan tidak berpengaruh terhadap kepatuhan wajib pajak UMKM $e$ commerce. Hal tersebut dibuktikan dengan nilai signifikannya $0,325>0,05$ dan memiliki nilai unstandardized coefficients B sebesar 0,147 sehingga $\mathrm{H}_{3}$ tidak terdukung. Hasil pengujian ini membuktikan bahwa sanksi perpajakan yang rendah akan meningkatkan kepatuhan wajib pajak UMKM e-commerce dan sebaliknya apabila sanksi perpajakan tinggi maka menurunkan kepatuhan wajib pajak UMKM e-commerce. Sanksi perpajakan merupakan pandangan yang buruk mengenai dampak yang akan ditimbulkan dari sanksi perpajakan. Wajib pajak memikirkan rendahnya resiko yang akan didapatkan ketika terlambat menyetor, melaporkan dan membayar kekurangan pajak penghasilan sebelum dilakukan pemeriksaan dari aparat pajak. Hal tersebut akan mengurangi kepatuhan wajib pajak.

\section{SIMPULAN}

Berdasarkan hasil pengujian dalam penelitian ini bahwa variabel Sosialisasi perpajakan berpengaruh positif terhadap kepatuhan wajib pajak UMKM $e$ commerce dan Sanksi Perpajakan tidak berpengaruh terhadap kepatuhan wajib pajak UMKM e-commerce. Penelitian ini memiliki keterbatasan karena penelitian ini hanya menggunakan satu sumber data penelitian, yaitu kuesioner. Dengan demikian, kesimpulan yang diambil berdasarkan data yang terkumpul hanya melalui kuesioner tersebut. Kuesioner juga memiliki keterbatasan, yaitu terkadang jawaban yang diberikan oleh responden tidak menunjukan keadaan yang sebenarnya. Hal ini bisa terjadi karena responden yang tidak objektif atau responden yang tidak memahami maksud dari pertanyaan yang tertulis dalam kuesioner.

Saran untuk peneliti selanjutnya adalah diharapkan dapat menggunakan variabel independen lain selain yang digunakan dalam penelitian ini, baik dengan cara penggantian variabel dependen misalnya pemahaman perpajakan dan penerapan akuntansi atau variabel independen misalnya transaksi UMKM ECommerce dan diharapkan peneliti selanjutnya juga dapat memperluas cakupan wilayah penelitian dan jumlah sampel yang lebih besar, sehingga hasil penelitian dapat digeneralisasi untuk wilayah Indonesia. Untuk meminimalkan bias hasil penelitian penelitian akibat persepsi responden berbeda dengan kondisi yang sesungguhnya, penelitian selanjutnya diharapkan dapat melakukan wawancara untuk menguji kebenaran jawaban responden. Penelitian selanjutnya juga 
dapat mengembangkan penelitian ini dengan menggunakan metode penelitian yang berada seperti metode eksperimen atau pendekatan kualitatif.

\section{REFERENSI}

Arabella, \& Yenni. (2013). Pengaruh Kualitas Pelayanan, Sanksi Perpajakan dan Biaya Kepatuhan Terhadap Kepatuhan Wajib Pajak. pp. 452-470.

Arisandy, N. (2017). Pengaruh Pemahaman Wajib Pajak, Kesadaran Wajib Pajak dan Sanksi Pajak terhadap Kepatuhan Wajib Pajak Orang Pribadi yang Melakukan Kegiatan Bisnis Online di Pekanbaru. pp. 62-71.

As'ari, N. G., \& Erawati, T. (2018). Pengaruh Pemahaman Peraturan Perpajakan, Kualitas Pelayanan, Kesadaran Wajib Pajak dan Sanksi Pajak terhadap Kepatuhan Wajib Pajak Orang Pribadi. 46-55.

Ayuwuragil, K. (2017). Kemenkop UKM: 3,79 Juta UMKM Sudah Go Online.

Cindy, J., \& Yenni, M. (2013). Pengaruh Kesadaran Wajib Pajak, Kualitas Pelayanan Fiskus, Sanksi Perpajakan, Lingkungan Wajib Pajak berada Terhadap Kepatuhan Wajib Pajak Orang Pribadi di Surabaya. Tax \& Accounting Review.

Damian Farrow \& Joseph Baker, A. C. M. (2015). Pengaruh Sosialisasi Perpajakan, Tarif Pajak, dan Pemahaman Perpajakan Terhadap Kepatuhan Wajib Pajak. 10-17.

Darmawati, D., \& Oktaviani, A. A. (2018). Pengaruh Penerapan Akuntansi UMKM Terhadap Kepatuhan Wajib Pajak UMKM E-Commerce. pp. 919-925.

Ghozali. (2018). Tujuan Uji Normalitas. In Aplikasi Analisis Multivariate dengan Program IBM SPSS 19. Semarang.

Hestanto. (2018). Kepatuhan Wajib Pajak. Jurnal Akuntansi \& Ekonomi, 2-19.

Hoetoro, A., Editor, S., Tohari, A., Puspita,
E., Kurniawan, A., Kusumaningtyas, D., ... Solikah, M. (n.d.). Pengaruh Kesadaran dan Pengetahuan Wajib Pajak Terhadap Kepatuhan Wajib Pajak. Jurnal Akuntansi \& Ekonomi.

Pandapota, \& Ritonga. (2011). Analisis Pengaruh Kesadaran dan Kepatuhan Wajib Pajak terhadap Kinerja Kantor Pelayanan Pajak (KPP) dengan Pelayanan Wajib Pajak sebagai Variabel Intervening Di KPP Medan Timur.

Pertiwi. (2017). Pengaruh Pengetahuan Perpajakan, Sanksi Perpajakan dan Kesadaran Wajib Pajak terhadap Kepatuhan Wajib Pajak Badan pada KPP Pratama Cilacap.1689-1699.

Putra, A. H., Aswari, A., Arifin, M. Y., \& Rina, R. (2018). Quantitative Series: Factors Analysis Effects of Government Regulation Number 46 the Year 2013 For SME's by Justice, Convenience, and Simplicity of Tax Aspects. Substantive Justice International Journal of Law, 1(2), 19-65.

Nur Rohmawati, A., \& Rasmini, N. (2012). Pengaruh Kesadaran, Penyuluhan, Pelayanan, Dan Sanksi Perpajakan Pada Kepatuhan Wajib Pajak Orang Pribadi. E-Jurnal Akuntansi.

Rahayu, N. (2017). Pengaruh Pengetahuan Pajak, Self Assestment System dan Sanksi Pajak Terhadap Kepatuhan Wajib Pajak. Jurnal Akuntansi.

Rosalinawati, \& Emma. (2015). Analisis Pajak Penghasilan Atas Transaksi ECommerce Di Kabupaten Gresik.

Republika.co.id. (2018). Kepatuhan Pengusaha UMKM Membeyar Pajak Rendah

Katadata. (2019). Berapa Pengguna Media Sosial Indonesia. Retrieved Juni 2019, from Katadata: https://databoks.katadata.co.id/datap ublish/2019/02/08/berapa-penggunamedia-sosial-indonesia

Septarini, D. (2015). Pengaruh Pelayanan, Sanksi, Dan Kesadaran Wajib Pajak Terhadap Kepatuhan Wajib Pajak 
Orang Pribadi Di Kpp Pratama Merauke. Jurnal Ilmu Ekonomi \& Sosial, pp. 29-43.

Siamena, E., Sabijono, H., \& Warongan, J. D. . (2017). Pengaruh Sanksi Perpajakan Dan Kesadaran Wajib Pajak Terhadap Kepatuhan Wajib Pajak Orang Pribadi Di Manado. Jurnal Riset Akuntansi, pp. 917-927.

Siat, C. C., \& Toly, A. A. (2013). FaktorFaktor yang Mempengaruhi Kepatuhan Wajib Pajak dalam Memenuhi Kewajiban Membayar Pajak Di Surabaya. Petra Christian University Tax and Accounting Review.

Sudrajat. (2015). Pemanfaatan Teknologi Informasi, Sosialisasi Pajak, Pengetahuan Perpajakan, dan Kepatuhan Pajak. Jurnal Riset Akuntansi Dan Perpajakan.

Susilawati, K. E., \& Budiartha, K. (2013). Pengaruh Kesadaran Wajib Pajak, Pengetahuan Pajak, Sanksi Perpajakan dan Akuntabilitas Pelayanan Publik pada Kepatuhan Wajib Pajak Kendaraan Bermotor. EJurnal Akuntansi Universitas Udayana, pp. 2302-8556

Suwardjono. (2011). Pengaruh Penghasilan dan Kesadaran Wajib Pajak terhadap Kepatuhan Wajib Pajak dalam Membayar Pajak Bumi dan Bangunan (PBB) di Kelurahan Tembalang Semarang.

Sugiyono. (2016). Memahami Penelitian Kualitatif. Alfabeta: Bandung.

Sugiyono, P. D. (2016). Metode Penelitian Kuantitatif, Kualitatif, dan $R \& D$. Alfabeta: Bandung

Syahrul. (2012). E-Commerce sebagai Solusi Pemasaran bagi Usaha Mikro
Kecil Dan Menengah (UMKM).

Syaiful, R. (2016). Pengaruh Kesadaran Wajib Pajak, Administrasi Perpajakan, dan Sanksi Pajak terhadap Kepatuhan Wajib Pajak Pajak Bumi dan Bangunan. pp. 2-18.

Utami, R., \& Muzakir, M. (2016). Analisis terhadap Faktor-Faktor yang Mempengaruhi Wajib Pajak Orang Pribadi yang Melakukan Pekerjaan Bebas Untuk Membayar Pajak. Jurnal Akuntansi Trisakti.

Wardani. (2018). Pengaruh Sosialisasi Perpajakan terhadap Kepatuhan Wajib Pajak dengan Pengetahuan Perpajakan sebagai Variabel Intervening (Studi pada Wajib Pajak Orang Pribadi di KPP Pratama Kebumen).

Winerungan, O. L. (2013). Sosialisasi Perpajakan, Pelayanan Fiskus dan Sanksi Perpajakan terhadap Kepatuhan Wpop di KPP Manado dan Kpp Bitung. Jurnal Riset Ekonomi, Manajemen, Bisnis Dan Akuntansi, pp. 960-970.

Wulandari, T., -, A., \& Ilham, E. (2015). Pengaruh Sosialisasi Perpajakan, Pengetahuan Perpajakan, dan Kualitas Pelayanan terhadap Kepatuhan Wajib Pajak dengan Kesadaran Wajib Pajak sebagai Variabel Intervening (Studi Pada Kantor Pelayanan Pajak Pratama Pekanbaru Senapelan). Jurnal Online Mahasiswa Fakultas Ekonomi Universitas Riau.

Zulvina, S. (2014). Disharmonisasi UU Penagihan Pajak dan UU KUP dalam Rangka Penerimaan Pajak. 